\title{
'N Kerk Met KARAKter: Die Perspektief van Gerben Heitink
}

Author:

Theuns F.J. Dreyer ${ }^{1}$

\section{Affiliation:}

${ }^{1}$ Hervormde Teologiese

Kollege, Universiteit van

Pretoria, Suid-Afrika

\section{Correspondence to:}

Theuns F.J. Dreyer

e-mail:

theuns.dreyer@up.ac.za

\section{Postal address:}

Posbus 1208,

Hartbeespoort, 0216,

Suid-Afrika

\section{Keywords:}

ekklesiologie; ontluikende kerk; vernuwing; missionaat; publieke teologie

\section{Dates:}

Received: 13 July 2009

Accepted: 21 Aug. 2009

Published: 04 Nov. 2009

How to cite this article: Dreyer, T.F.J., 2009, "n Kerk met karakter: Die perspektief van Gerben Heitink', HTS Teologiese Studies/Theological Studies 65(1), Art. \#315, 5 pages. DOI: 10.4102/hts.v65i.315

\section{This article is available} at: http://www.hts.org.za
(C) 2009. The Authors. Licensee: OpenJournals Publishing. This work is licensed under the Creative Commons Attribution License.

\section{ABSTRACT}

\section{A church with character: The perspective of Gerben Heitink}

Mainstream churches worldwide are experiencing a decline in membership. The wellknown Dutch practical theologian Gerben Heitink's (2007) latest book Een kerk met karakte, Tijd voor heroriëntatie is an attempt to address this phenomenon. This article is an overview of his book, with comments from other authors. Although emerging churches is constitute a movement separate from the institutional churches, Heitink still takes the existing church as point of departure. He suggests a process of reorientation and transformation within based on a matrix of eight critical factors. In conclusion, the article evaluates Heitink's model from a personal perspective within the context of the Netherdutch Reformed Church of Africa.

\section{TERREINVERKENNING}

Dat die tradisionele hoofstroomkerke wêreldwyd 'n krisis beleef, hoef eintlik geensins verder betoog te word nie. Talle publikasies wat hierdie probleem identifiseer, ontleed en na oplossings soek, het in die afgelope paar dekades die lig gesien (Hall 1995:19-21; Niemandt 2007:12-15). Hoekendijk (1964) het met sy bekende boek De Kerk binneste buiten in die tweede helfte van die vorige eeu al hierdie gevaartekens aangetoon, en vir radikale verandering gepleit. Sedertdien kom kerke al hoe meer voor die realiteit van 'n drastiese verlies aan lidmate te staan Heitink (2007) wys daarop dat die Protestantse Kerk in Nederland jaarliks ongeveer $2 \%$ van haar lidmate verloor. In die praktyk kom dít neer op 65000 lidmate per jaar, of anders gestel, 65 groot gemeentes per jaar - meer as 'n gemeente per week! Volgens Heitink het buitekerklikheid in Nederland van 3\% in die jaar 1900, tot $40 \%$, of volgens ander opnames tot selfs 65\%, in 2000 gestyg. Na raming sal slegs 4\% van die Nederlandse bevolking teen 2020 nog tot die Protestantse Kerk behoort (De Roest \& Stoppels 2007:12). Knippenberg (2005:3) is van mening dat die kerklike situasie in Europa 'n krisis begin aanneem.

In die Verenigde State van Amerika (VSA) het die getal volwassenes wat nié meer eredienste bywoon nie vanaf 1991 tot 2001 van 39 miljoen tot 75 miljoen aangegroei (Barna 2005). Hoewel die impak van die sekularisasieproses Suid-Afrika eers later as Europa en die VSA getref het, toon plaaslike kerklike statistieke nader aan die eie kring dieselfde tendens. Gereformeerde kerke se 'markaandeel' onder die blanke bevolkingsgroep in Suid-Afrika het in 1911 op 51,7\% gestaan. In 1996 het dit tot 48,1\% afgeneem (Dreyer 2003:1050). Dr Wim Dreyer het namens die Raad van Apostolaat van die Nederduitsch Hervormde Kerk van Afrika (hierna NHKA) navorsing gedoen oor kerklike tendense in Suid-Afrika, en meer bepaald die toedrag van sake in die NHKA (NHKA 2009). Volgens die verslag wat uit sy navorsing spruit, toon lidmaatskap van die tradisionele drie Afrikaanssprekende kerke dieselfde tendense. In hierdie kerke het dooplidmaatsyfers in die afgelope twee dekades met $65 \%$ gedaal. Lidmaatsyfers van die NHKA het die afgelope 20 jaar met 30\% verminder. Indien hierdie tendens voortduur, kan die NHKA na verwagting binne die volgende tien jaar ' $n$ inploffing van lidmate beleef, met gepaardgaande katastrofiese gevolge vir die Kerk. Gemeentes sal moet sluit, predikante sal uit die bediening moet tree, en die Kerk sal moeilik op sinodale vlak oorleef.

Sweet (1999:45-65) skryf in sy boek, SoulTsunami, sink or swim in new millenium culture, dat indien die kerk nie radikale aanpassings maak nie, hierdie nuwe gety die kerk gaan laat sink. In 'n latere werk gebruik hy die beeld van die tradisionele kerklidmate as immigrante in 'n nuwe, vreemde wêreld (Sweet 2001:11-16). Hirsch (2006:36) is van mening dat nóg die pogings van tradisionele hoofstroomkerke nóg dié van plaaslike gemeenskapskerke of onafhanklike megakerke die toename in ongeloof en buitekerklikheid kan stuit. Sommige teoloë is oortuig dat die tyd van die tradisionele kerk verby is; dat dit geen kans het in die postmoderne wêreld nie. Party gaan selfs so ver om te sê dat denominasionele strukture die koninkryk van God in die wiele ry (Niemandt 2007:38). Die vraag is of die kerke deel van die probleem of deel van die oplossing is (Ward 2002:13).

Van Aarde (2008:1213-1234) pleit vir 'n publieke teologie as antwoord op die verleentheid van die kerk, omdat 'n nuwe 'opkomende Christelikheid' ('emerging christianity') parallel met die kerk aan die ontwikkel is, en ander soekende gelowiges verkies om in die openbare domein ('public square') te bly. Publieke teologie is volgens hom nie teoloë wat teologie in die openbare domein, of op die markplein, beoefen nie, maar mense wat in die openbare domein met 'Godspraatjies' ('God talk') besig is. Hy verwoord sy siening van hierdie publieke teologie soos volg: '...what I call the inarticulate longing of believers who do not want to belong' (Van Aarde 2008:1217). Sulke mense wat hulle 'alternatiewe' geloof beoefen, kan ook volgens hom as alternatiewe geloofsgemeenskappe, of as '...the church on the other side or even churchless Christianity', beskou word (Van Aarde 2008:1217). As eksemplaar van die denke in die opkomende kerk, wil Young (2007:179) deur sy uitbeelding van Jesus dit duidelik stel dat Jesus nie in instellings en godsdiens as menslike skeppings belang stel nie.

Teen hierdie agtergrond is dit te verstane dat die tradisionele kerke in die laaste tyd ernstig oor die ekklesiologie besin. In Nederland het twee praktiese teoloë gepoog om 'n prakties-teologiese ekklesiologie te omlyn, om in hierdie nuwe verband weer vir geloof en kerkwees die koers aan te dui (kyk Dingemans 2005; Heitink 2007). In eie geledere het Buitendag (2006:351) van die NHKA al die uitspraak 
gemaak dat ons moet wegbeweeg '...van 'n soliede kerk as bloot die bymekaarkom van uitverkorenes op 'n spesifieke tyd en plek. Kerk is eerder 'n vloeibare kommunikatiewe netwerk van verhoudinge'.

Die doel van hierdie artikel is om teen voormelde agtergrond in die besonder die werk Een kerk met karakter. Tijd voor heroriëntatie (2007) van Gerben Heitink oorsigtelik te bespreek, en terselfdertyd na moontlike insigte te soek wat in besonder die NHKA in die huidige krisis tot hulp kan wees.

\section{'N KERK MET KARAKTER}

'Van de kerk moet in deze situasie verwacht worden dat zij karakter vertoon. Het is tijd voor heroriëntatie' (Heitink 2007:356). Hierdie uitspraak van Heitink vat die bedoeling van sy boek goed perfek saam. Venter (2008:26) meen

[Heitink se] oortuiging is dat die kerk ' $n$ integrale deel van die voortgang en groei van die Christelike tradisie is en dat die Christelike tradisie nie sonder die kerk as sosiale verband en voorlopige gestalte van die koninkryk van God in hierdie wêreld kan funksioneer nie.

Venter (2008:26)

Die kerk sal die oorspronklike en ware karakter van kerkwees in hierdie nuwe konteks moet herontdek om steeds as kerk voort te bestaan. Dít vra egter van die kerk die moed vir ' $n$ algehele en ingrypende herreoriëntasie om as die teenkultuur of alternatiewe geloofsgemeenskap vir vandag te dien. Hierdie herreoriëntasie kan ook nie juis veel langer uitgestel word nie. Die kerk bevind hom in 'n kairos-oomblik; die tyd is ryp (Heitink 2007:2). ${ }^{1}$

Heitink voer aan dat sy boek as 'n prakties-teologiese verantwoording met die karakter van 'n prakties-teologiese ekklesiologie of ekklesiastiek beskou moet word (Heitink 2007:340). Hiervoor gebruik hy Firet (1986:589) se omskrywing, wat ekklesiastiek as die teologiese teorie oor die sosiale gestalte van die Christelike geloof beskou - die verwerkliking van ' $n$ belofte as gegewe moontlikheid; die vervulling van 'n opdrag in 'n bepaalde maatskaplike en kulturele situasie. In sy model maak hy gebruik van sosiaalwetenskaplike en teologiese metodes wat op mekaar inwerk. Dit is volgens hom 'n dinamiese model wat, in die woorde van Moltmann, in die kragveld van die Gees afspeel (Heitink 2007:339). Hy noem dit ook 'n heuristiese of 'metodies-soekende' model.

Die verdienstelikheid van sy benadering lê daarin dat hy as praktiese teoloog nie slegs ' $n$ ekklesiologie aan die hand van dogmatiese, kerkregtelike, of selfs Bybelse perspektiewe probeer ontwerp nie, maar dat hy 'n holistiese benadering met ' $\mathrm{n}$ ontvanklikheid vir sosiaalwetenskaplike insigte volg. Hy gebruik die bekende drieslag (Heitink 2007:25), naamlik 'n ontleding van die situasie (empiriese perspektief), teologiese oordenking (hermeneutiese perspektief) en voorstelle vir 'n beleid (strategiese perspektief). Aan die hand van Van Aarde (2008:1217) se omskrywing van publieke teologie, sal Heitink se poging nie as publieke teologie beskou kan word nie, maar as 'n teoloog wat teologie in die openbare domein wil beoefen. Volgens Dreyer (2004:919) wil so 'n prakties-teologiese benadering die teologie met die kontemporêre kultuur in gesprek bring.

\section{MATRIKS VIR HEITINK SE EKKLESIOLOGIE}

Om sy lesers te oriënteer bespreek Heitink die faktore wat volgens hom die hoofoorsake van die huidige stagnasie in die kerk is (Heitink 2007:20-23). Stagnasie is nie versoenbaar met dié kerk wat die kerk van die Here is nie. Die teologiese grondpatroon van die kerk kan nie tot stagnasie lei nie, want die kerk is die volk van God wat onderweg is - die liggaam van Christus; die

1.Sweet (2001:16) meen dat die tyd waarin ons leef so snel verander dat die tradisionele spreekwoord carpe diem nie meer van toepassing kan wees nie, want dan is dit reeds te laat. Hy pleit dat die kerk gereed moet wees vir carpe manana, met ander woorde 'gryp die dag van môre': 'By the time you Carpe Diem, it is already met ander woorde 'gryp die dag van môre': 'By the time you Carpe Diem, it is already
too late. We need to learn how to, in the words of a live not dead language, Carpe Manana, "seize tommorow" or "seize the future". tempel van die Gees; die bruid van Christus (Heitink 2007:2528). Hierdie Bybelse metafore is volgens hom lynreg in stryd met enige vorm van stagnasie. Vervolgens bespreek hy kortliks die bekende notae ecclesiae van die kerk, naamlik eenheid, heiligheid, katolisiteit en apostolisiteit, wat as die uitgangspunt vir sy ekklesiologiese ontwerp dien (Heitink 2007:28-32). As daar oor die kerk as instelling gepraat word, gaan dit oor die wesensvraag van die kerk soos die klassieke formulering van die Apostoliese Geloofsbelydenis en die Nicenum dit verwoord, terwyl die kerk as organisme weer vanuit die lewende communio sanctorum beskou moet word (kyk Barth 1959:141; Berkhof 1979:343).

In 'n voëlvlug oor die kerkgeskiedenis onderskei Heitink 'n voorChristelike tydperk tot en met die jaar 380, toe die Christendom 'n staatsgodsdiens geword het. Die tweede tydperk is die Christelike of die Konstantynse tydperk. Die derde is 'n postChristelike tydperk, wat volgens hom uiteindelik omstreeks 1960 deurgebreek het (Heitink 2007:32-36). In die Konstantynse tydperk het die kerk so verweef geraak met die staat dat die sogenaamde corpus Christianum tot stand gekom het. Saam met G.J. Heering tipeer hy hierdie oorgang as die sondeval van die Christendom (Heitink 2007:33). Vanuit 'n magsposisie in die corpus Christianum het die kerk in die post-Christelike era haar greep op die kultuur verloor, en haar kort voor lank as instelling in ' $\mathrm{n}$ minderheidsposisie bevind. ${ }^{2}$ Hierdie weerlose posisie van die kerk moet egter nie slegs negatief bejeën word nie, want dit '...strookt meer met haar aard dan gemakkelijke staatssteun of volksgunst' (Heitink 2007:36).

In sy ekklesiologiese model gebruik Heitink agt faktore as merkers wat hetsy daartoe kan lei dat die kerk haar tersaaklikheid verloor, of deur herreoriëntasie kan help om stagnasie te bowe te kom. Vier van hierdie agt faktore, naamlik inkulturasie, integrasie, evangelisasie en organisasie, verteenwoordig die kerk se doelstellings as instelling. Die ander vier, naamlik inisiasie, partisipasie, kongegrasie en kontemplasie, verteenwoordig weer die kerk se funksies as gemeenskap (Heitink 2007:338). As grondslag vir sy ekklesiologiese model gebruik hy Berkhof se drievoudige konstruk wat die kerk as instelling, as gemeenskap, en as die dinamiese wisselwerking tussen dié twee beskou (Venter 2008:30). In hierdie model is daar middelpuntvliedende kragte van binne na buite, sowel as middelpuntsoekende kragte wat van buite na binne werk. Die agt voormelde faktore word vervolgens kortliks onder die loep geneem.

\section{Inkultivering}

Inkultivering is een van die doelstellings van die kerk as instelling. Die kerk is altyd kerk in 'n konkrete verband. Kultuur is die natuurlike leefomgewing van die mens, en daarom ook dié van die kerk. Heitink tref ' $n$ onderskeid tussen inkultivering en akkultivering. Laasgenoemde is die aanpassing by die heersende kultuur, terwyl eersgenoemde die indringing van die kerk in ' $\mathrm{n}$ vreemde kultuur veronderstel. ${ }^{3}$ Dit vra in baie gevalle aanpassings, en in ander gevalle die ontwikkeling van 'n teenkultuur (Heitink 2007:38). Die kultuurbreuk van die sestigerjare het daartoe gelei dat die heersende gesagskultuur van alle kante op die proef gestel word. Die tradisionele gesag van ouers, onderwysers, politici en kerklike leiers word nie meer as formele gesag erken en aanvaar nie. Sekularisasie het die lewensgebiede in die samelewing wat onder beheer van die kerk was, geneutraliseer. Godsdiens word tot mense se persoonlike leefwêreld teruggedruk (Heitink 2007:54). Die

2.W.A. Dreyer (2006:1337-1368) toon hoe die NHKA deur haar volkskerklike denke uiteindelik as instelling gestagneer het. Callahan (2002:16) lys aan die hand van sekere begrippe ' $n$ twintigtal eienskappe wat die verskil tussen die kerk as instelling en organisme omlyn. Hierdie kenmerke van die kerk as instelling kom ook duidelik in Heitink se beskouing oor die Protestantse Kerk in Nederland na vore. Dit toon ook ooreenkomste met Niemandt (2007.21-23) se vergelyking tussen modernisme on postmodernisme as uitdaging vir die kerk om wer as lewssen modernisme en postmodernisme as uitdaging vir die kerk om weer as lewende organisme te
funksioneer.

3.Sweet (2001:19) vergelyk hierdie uitdaging waarvoor die kerk te staan gekom het

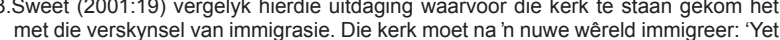
met die verskynsel van immigrasie. Die kerk moet na'n nuwe wêreld immigreer: 'Yet
the difference between the world of immigrants and the world of the natives is not the difference between the world of immigrants and the world of the natives is not
one of degree, but of kind, a difference not of differentia but of genus itself.' 
deurbreek van die Verligting het geloof in God en lidmaatskap van ' $n$ kerk hulle vanselfsprekendheid laat verloor. Die moderne lewenservaring het die mens se vryheid, onafhanklikheid en selfstandigheid beklemtoon. God en sy voorsienigheid het op die agtergrond verdwyn. Die postmoderne lewenservaring het op sy beurt gefragmenteerd geraak met die klem op die individu, en die klein verhale wat die meesternarratiewe in twyfel trek. Die waarheidsvraag kan dus slegs op 'n persoonlike vlak beantwoord word:

Dit levensgevoel kent ook een grotere openheid voor religie, in een modern levensklimaat agterhaald door de rede, maar in onze tijd teruggekeerd via het gevoel, als de expressie van de meest individuele emoties. De waarheidsvraag maakt plaats voor de zinvraag.

(Heitink 2007:62)

In hierdie nuwe kulturele omgewing sal die kerk daarteen moet waak om haar nie binne haar vier mure terug te trek nie, maar sal sy juis ' $n$ nuwe visie moet ontwikkel om deur ' $n$ proses van inkultivering die nuwe wêreld in te gaan: 'De kerk kan geen enkele cultuur omarmen, maar zal zich ook in een postmoderne cultuur kritisch moeten opstellen' (Heitink 2007:74). Gelowiges moet toegerus word om in hulle daaglikse lewe Christene te wees, want daardeur word die kerk die duidelikste sigbaar. Teoloë en filosowe sal hulle normatiewe visie na die openbare debat moet bring. Vir Heitink is dit van groot belang dat die kerk by die nuwe religiositeit aansluiting soek (Heitink 2007:75). ${ }^{4}$

\section{Inisiasie}

Met inisiasie het Heitink inwyding of inlywing in die oog: 'De kerk is geen vereniging van belanghebbende maar een geloofsgemeenschap waarbinnen een mens moet worden ingewijd' (Heitink 2007:79). Dít gebeur via opvoeding, onderrig en die meedoen aan rituele. Op hierdie manier word die Christelike tradisies van geslag tot geslag oorgedra. Waar die proses stagneer, sterf die kerklike gemeenskap stadig maar seker uit. Vanuit die kulturele antropologie onderstreep Heitink die belang van inwyding vir die geloofsgemeenskap. Te midde van 'n postmoderne lewensklimaat, waar 'n gesagskrisis, bevraagtekening van norme, en wat hy ' $n$ 'pedagogiese paradoks' noem aan die orde van die dag is, bepleit hy juis die noodsaak van die inlywingsproses. Die doop, kategese en belydenis van geloof moet in hierdie klimaat verder ontgin word as belangrike boustene van die inisiasieproses (Heitink 2007:94-116).

\section{Integrasie}

Integrasie is gerig op onderlinge samehang en verbondenheid: 'Een kerk kan alleen haar identiteit bewaren wanneer zij te midde van de veelheid op zoek gaat naar eenheid. Dat is haar oecumenische roeping' (Heitink 2007:117). Differensiasie as sosiologiese verskynsel het in die kerk tot pluralisering op die vlak van die samelewing en die individu aanleiding gegee, met gevolglike verbrokkeling van gemeenskappe en tradisies. Eenheid word bedreig deur verskeidenheid. Eenheid kan nie meer deur magstrukture gehandhaaf word nie. Die groot uitdaging is om eenheid in verskeidenheid te handhaaf.

Heitink toon dat verskeidenheid deel van die vroegste Christelike tradisies was. Selfs die kanonvorming is ' $n$ bewys van eenheid in verskeidenheid. Op die voetspoor van Gerd Theissen toon hy aan dat die vier strome van die Judese, Sinoptiese, Pauliniese en Johannese Christendom elk in die kanon sy plek het. As uitgangspunt wat eenheid in verskeidenheid betref, vervul die 'Sache Jesu' ' $n$ kernrol as samebindingsfaktor (Heitink 2007:121-148). As herreoriëntasie stel Heitink 'plurivormigheid'

4.Niemandt (2007:10) beskou hierdie nuwe era nie noodwendig as ' $n$ bedreiging vi die kerk nie. Op die voetspoor van Sweet (1999) se SoulTsunami sien hy dit as ' $\mathrm{n}$ perfekte storm wat aan die kerk nuwe moontlikhede en geleenthede bied.

5.Die vraag is of dit net jongmense is wat in die kerklike gemeenskap ingelyf moet word, en of dit dalk, soos wat Sweet (1999:19) dit stel, eers moontlik sal wees indien die ouer geslag ook bereid is om ingelyf te word in die nuwe wêreld waarin jongmense die 'inheemse bevolking' is en die ouer garde die 'immigrante'. ('pluriformity') as 'n gegewe in die ekklesiologiese besinning, maar wel 'n plurivormigheid wat deur die 'Sache Jesu' saamgebind word. Daar sal bepaalde spelreëls moet wees om rigtings en modaliteite te rig, omdat geen deelbelang die voortgang van die kerklike lewe kan belemmer nie ${ }^{6}-{ }^{\prime}[\mathrm{g}]$ een traditie heeft de waarheid in pacht; de waarheid zal in elke generatie opnieuw langs hermeneutische weg op een weerbarstige werkelijkheid heroverd moeten worden. Daarin ligt de actualiteit en de urgentie van het thema integratie' (Heitink 2007:152). ${ }^{7}$

\section{Deelname}

Deelname het te make met kerklike betrokkenheid. Tradisioneel word kerklike betrokkenheid deur lidmaatskap bepaal. Daarom is die teleurstelling so groot as dit blyk dat lidmaatsyfers sterk aan die afneem is. Deelnamepatrone het egter verander. Ledetalle en lidmaatskap is nie meer die oorheersende barometer vir geloof nie. Deelname het dus nie meer slegs op binnekerklike gebruik betrekking nie, maar is ' $n$ gerigtheid op die deelname van Christene in samelewingsverband.

Heitink verwys na die kerk as sosiale gestalte, en wel aan die hand van drie kerksoorte, naamlik die publieke kerk as volkskerk, as vrye kerk en as die mistieke, spirituele of charismatiese kerk. Hierdie ou begrip van sosiale samehang het vir die moderne netwerkbegrip plek gemaak, wat ook as die 'vloeibare kerk' ('liquid church') beskryf kan word. Lidmaatskap word nie noodwendig met erediensbywoning verbind nie, maar die klem val eerder op ontmoetings in ander sosiale verbande. Persoonlike geloof en oorgawe aan Jesus word nou die kenmerke (Heitink 2007:153-169). Hy bepleit ' $n$ model van konsentriese gemeentevorming, wat van binne na buite én van buite na binne uitkring. Die onderskeid tussen binne en buite moenie beklemtoon word nie, maar moet eerder gerelativeer word. Dit is dus ' $n$ dubbelbeweging van binne na buite én van buite na binne met betrekking tot die lewende middel, die 'Sache Jesu'. Hierdie benadering hou rekening met sirkels van betrokkenheid en met middelpuntsoekende én middelpuntvliedende kragte wat alles hier aan die werk is (Heitink 2007:180).

\section{Evangelisasie}

'n Kerk wat ontvanklik is vir kultuur, en hierdie ontvanklikheid terselfdertyd met trou aan haar tradisie en identiteit in die 'Sache Jesu' verbind, nooi mense om deel te neem. Hiervoor gebruik Heitink die term 'evangelisasie'. Hy vertolk dit, anders as apostolaat, sending of missionaat, as die vrymoedigheid om vir ons geloof na vore te tree. Dit veronderstel geen aanmatiging nie, maar eerder aanwesigheid in algehele beskeidenheid, empatie en kliëntevriendelikheid. In evangelisasie gaan dit vir hom om die eenheid van woord en daad; van getuienis en diens. Die oorkoepelende begrip hiervoor is diakonia (Heitink 2007:190-195). Dit is 'n oop aanbod - nie opdringerig nie, maar altyd uitnodigend. ${ }^{8}$

6.T.F.J. Dreyer (2006:1302) beskou die inagneming en bestuur van diversiteit as die grootste uitdaging waarvoor die kerk te staan kom. Armour en Browning (1995) het in hierdie verband deeglike navorsing gedoen oor die verskynsel van denkstelsels en die invloed wat dit op die kerk het. Hulle poog om stelselsensitiewe leierskap te ontwikkel om die werklikheid van diversiteit tot voordeel van die kerk te ontgin.

7.Sien ook die insiggewende publikasie van Bell (2005:41-69) wat beklemtoon dat dit juis dee van ituasie nuut te vertol. Daar is volgens hom te veel aansprake dat h bepaalde groepering of kerk die Byber verk vertolking van die Bybel is. Alle Christellke kerke verkondig immers die Bybel. As ons erken dat ons besig is met ons vertolking van die Bybel, sal die aansprake dat dit die enigste moontlikheid is, vervaag, en word diversiteit makliker verdra.

8.Die begrip 'missionale (Hierdie begrip moet behou word omdat dit juis ' $n$ ander betekenis het as missionêre) kerkwees kan nog maklik die indruk wek van ' $\mathrm{n}$ gesaghebbende of paternalistiese opset as dit nie werklik vanuit 'n diakonale diensmotief benader word nie. Dít is waarskynlik waarom Heitink die begrip 'evangelisasie' verkies. Hierdie begrip het egter steeds die konnotasie van om dié wat buite die kerk is, in te bring terwyl die missionat juis klem lê op die kerk die 'wat buil' die kerk is, in te bring, ter. se 'sending' die wereld in. In die missionaat gaan dit nie daarom om lidmate vir die kerk te wef ie, maar om mense met die aanraking te bring. Die missionaat is 'n bestaanswyse van mense wat self die liefde van Christus in hulle lewe ervaar het, en dit diakonaal met ander wil deel. 


\section{Gemeentelikheid}

Gemeentelikheid dui op die samekoms van die lidmate in 'n gemeente. In hierdie gedeelte voer Heitink die gedagte van 'n konsentriese kerk verder. Die kern van die saak is ' $n$ gemeente wat saamkom om haar geloof te bely en te vier. Die kern is egter nie die kerngemeente self nie, maar die geheimenis waarop alles toegespits is, naamlik die aanwesigheid van Jesus Christus deur sy Gees. Die gemeente sentreer draai voortdurend om hierdie geheimenis sonder om dit ooit ten volle te deurgrond, maar dit weerhou haar nie daarvan om met volharding daarna te bly soek nie (Heitink 2007:226). Prediking en liturgie is hier die sentrale begrippe. In ons tradisie staan die prediking sentraal, met die liturgie as die viering van die heil. Dit verg sorgsame en selfstandige eksegese, en die egtheid om met hartstog die 'water uit die rots' te voorskyn te bring. Hierdie hartstog en egtheid moet voelbaar word in die konkrete omstandighede van die dag, en moet tot uiting kom in die verskillende lirurgiese handelinge. Kinders maak deel uit van, en hoort in, die kerk. Naas kinderkerk moet kinders ook in gewone eredienste by die liturgie en die prediking betrek word. Die herhaaldelike gevolgtrekking dat die erediens se dae getel is, is vir Heitink voorbarig en oppervlakkig. Eredienste is vir alle tye - ook vir die tyd waarin ons leef (Heitink 2007:258). ${ }^{9}$

\section{Organisasie}

Die organisasie van die kerk is nie ' $n$ doel op sigself nie, maar 'n middel in diens van Jesus Christus. Organisasiestrukture is hardnekkig, en daarom is dit nie so maklik om te verander nie (Heitink 2007:261). Die Bybel bevat geen bloudruk daarvoor nie - nouliks aanknopingspunte. Die territoriale organisasie van die kerk is die gevolg van 'n reëling onder keiser Karel die Grote wat bepaal het dat die kerk geografiese grense moet hê. Die omstandighede van Calvyn in Geneve het hierdie territoriale siening van kerkwees, sowel as die rol van die ampte, bevestig (Heitink 2007:261-267). Heitink is 'n voorstander van 'n aangepaste presbiteriaal-sinodale stelsel van kerkregering, met ' $\mathrm{n}$ groter bevoegdheid aan die klassis as skarnier tussen die plaaslike en die landelike kerk. Samewerkingsooreenkomste tussen gemeentes, en groter bevoegdheid aan die klassis, is noodsaaklik: 'Elke pleidooi voor meer gesag van bovenaf moet gepaard gaan met meer democratische bevoegdheden van onderop, geen hiërarchie zonder democratie' (Heitink 2007:294). ${ }^{10}$

\section{Oordenking}

In 'n tyd wanneer die kerkgemeenskap meer ruimte vir 'n individualistiese kerksoort en 'n netwerkagtige gemeentestruktuur bied, staan of val die toekoms van die kerk met die geloofsinspirasie van haar lede. Oordenking is ontleen aan die spirituele tradisie, en het te make met vrome bepeinsing of religieuse besinning: 'Het is een zich begeven in een gewijde ruimte om daarbinnen iets van het goddelijke waar te nemen, te beschouwen' (Heitink 2007:299). In 'n postmoderne

9.Die samekoms van die gemeente kan nie as die voorwaarde vir mense se ontmoeting met God beskou word nie, maar as die byeenkoms van mense wat reeds van God se teenwoordigheid in hulle lewe bewus geword het, en dit saam met ander gelowiges wil vier en versterk. Hier speel die eenheid tussen liturgie en prediking 'n groot rol om juis die ervaring van 'n ontmoeting met God aan te help (Dreyer 2005:93-108). Lose (2003:200) is ten gunste van ' $\mathrm{n}$ retoriek van uitnodiging, wat daarop neerkom dat die gehoor genooi word om die wêreld van die predike te betree en die werklikheid deur sy oë waar te neem. Om dit te bereik moet . Enersyds bied deprodimt vir ander sienings in ' $\mathrm{n}$ raamwerk van velligheid en vyheid. Heitink is korrek as hy sê dat die prediking in die reformatoriese tradisie altyd sentraal sal staan, maar dan nie meer prediking as die gesaghebbende oorreding van mense nie, maar as die getuie wat mense nooi

10.Dingemans (2005:271) bepleit ' $n$ informeler benadering tot die kerk as instelling, wat hy met die metafoor van 'n rondetafel beskryf, en bepleit'n geloofsgemeenskap waar almal gelyk en welkom is. Hierdie rondetafelgemeenskap moet die funksie van ontmoeting, gemeenskap, uitnodiging en ook leerskool vervul. Die kerk is volgens hom in haar verskyningsvorm ' $n$ instelling, maar mag nooit in haar wese as instelling stagneer nie. Dingemans verkies ' $\mathrm{n}$ aangepaste Kongregasionalistiese model, terwyl Heitink eerder in die kader van 'n presbiteriaal-sinodale model model, terwyl Heitink eerde
beweeg (Venter 2008:66) lewenservaring is daar by mense ' $n$ ondogmatiese geloof wat by die gefragmenteerde beeld van die moderne mens pas. Mense word bedreig deur 'n gevoel van onsekerheid, wat deur 'n soeke na God gekenmerk word. Dít alles vereis spiritualiteit en geestelike verdieping. Daar word deesdae in sekere kringe van die predikant as 'misterievertolker' gepraat - iemand wat belas is met die bediening van die geheimenis (Heitink 2007:319). Dit gaan hier om ' $n$ kennis wat die verstand te bowe gaan. Daarvoor is ' $\mathrm{n}$ ruimte en geleentheid vir oordenking nodig. ${ }^{11}$ Aandag aan spiritualiteit is aandag aan die wortels, of die hart, van die geloof. Sorg vir lewensin en geloofservaring is die diepste vorm van singewing vanuit die Christelike tradisie. ${ }^{12}$

\section{TRANSFORMASIE EN BEOORDELING}

In die laaste hoofstuk van sy boek onder die opskrif 'Transformasie', beklemtoon Heitink (2007:331) die feit dat transformasie ál agt faktore insluit wat hy uitgewys het:

Wanneer ik spreek over transfomatie kan dat niet anders betekenen dan dat de kerk een radicaal veranderingsproses moet doormaken om in een postchristelijke tijdperk dienstbaar te kunnen zijn aan 'die Sache Jesu'.

(Heitink 2007:331)

Dit is duidelik dat Heitink diep onder die indruk is dat die kerk in sy huidige vorm as instelling en versorger nie die mas gaan opkom in wat hy die post-Christelike tydperk noem nie. 'n Mens sou verwag dat hy, soos baie ander, tot die gevolgtrekking sal kom dat die kerk as instelling se dae getel is. Mense het nie meer die kerk nodig om te glo en hulle spirituele ervarings met ander te deel nie - inteendeel, vir baie is die kerklike instelling 'n belemmering. Tog volg hy nie dié roete nie, maar is sy uitgangspunt dat die kerk 'n gegewe is. Ál uitweg uit die impasse is radikale verandering. Sy konsentriese model van kerkwees, met ' $\mathrm{n}$ beweging van binne na buite én omgekeerd, open wél nuwe perspektiewe wat die kerk uit haar geïsoleerdheid kan bevry.

Dit is ook duidelik dat hy holisties na die saak kyk. Dit help nie om slegs in enkele opsigte vernuwing te probeer bring nie. Ál agt faktore wat die kerk as instelling en as geloofsgemeenskap raak, is onderling verweef. 'n Totale herreoriëntasie is daarom nodig. Haar sensitiwiteit vir die tydsgees en lewenservaring van mense in hierdie post-Christelike tydperk open nuwe horisonne vir die kerk as ons die waagmoed het om die geleenthede te benut. Hierdie boek van Heitink kan op alle vlakke vir die kerk 'n nuttige hulpmiddel wees om die problematiek van kerkwees in ons tyd deur verskillende lense te bekyk, en kan as rigtingwyser dien om weer 'n kerk met karakter te word.

\section{DIE NHKA DEUR HEITINK SE LENS}

In die bestek van hierdie artikel is dit nie moontlik om alle fasette van die NHKA deur Heitink se oë te bespreek nie. Ek 'droom' derhalwe bloot, in die lig van die werklikhede van ons tyd, kortliks oor nuwe moontlikhede vir die NHKA. ${ }^{13}$ Saam met

11.Borg (2003:26) meen dat ons onder die invloed van die moderne era te veel klem op geloof as verstandelike aangeleentheid lê, en dat ons geloof as 'n saak van die hart met die klem op die ervaring verwaarloos. Hy beklemtoon die belang van geloof as hoofsaaklik ' $n$ aangeleentheid van die hart. Hy bring hierdie spirituele ervaring van geloof later in verband met die sogenaamde 'thin places', 'n begrip wat hy aan die Keltiese tradisie voteen. Hieclie 'dun' plekke is war die twee dimensie hy an die Kellese dimensies van de werklikid, nadike en heilige, deur die Gess met mekaar in aanaking kom. Dit kan letterlik, soos in die Keltiese tradisie, geografiese plekke wees, maar ook situasies en geleenthede waar ' $n$ mens se hart ontvanklik is. Die liturgiese ervaring kan ' $n$ 'dun' plek wees, maar ook situasies soos die geboorte van 'n kind, siekte, rousmart, die natuur, jou binnekamer, 'n koffiekroeg. Dit word plekke waar' $n$ mens meer ontvanklik is vir die raakvlakke van hierdie twee werklikhede. Hierdie dun plekke moet meer ontgin word vir oordenking (Borg 2003:155-166).

12. Enersyds het oordenking ook met ' $n$ bepaalde spiritualiteit en teologiese etos van n kerk of gemeente te make (kyk Dreyer 1998:289-314). Andersyds sal daar ruimte gebied moet word vir verskillende spiritualiteitsoorte, wat weer met mense se persoonlikheidsvoorkeure en denkstelsels verband hou (Dreyer 2006:12911309).

13.Na aanleiding van die titel van Niemandt se boek Nuwe drome vir nuwe werklikhede (2007) 
Heitink wil ek die NHKA as gegewe as uitgangspunt neem. Natuurlik het die NHKA as instelling reeds in baie opsigte gestagneer. Tog bied dié kerk in sy huidige vorm vir talle gelowiges 'n geestelike tuiste. Hierdie lidmate kan wél, soos in Heitink se konsentriese model, die binnekring vorm, en naas hierdie binnekring moet die ander konsentriese sirkels gevorm word in ' $n$ beweging van binne na buite én van buite na binne. Of hierdie bestaande lidmate egter gereed is daarvoor wek by my twyfel. Hoewel dit reeds in sommige gemeentes gebeur, is die meeste gemeentes se siening van kerkwees van so'n aard dat dit hierdie dubbele beweging sal strem. Van buite beskou, is dit ook ' $n$ vraag of mense wat reeds die kerk die rug gekeer het as gevolg van dít wat hulle in die kerk as instelling ervaar het, weer deel van hierdie konsentriese kerkbeskouing sal wil wees. Die bestaande gemeentes van die NHKA sal ' $n$ proses van radikale transformasie op ál agt vlakke van Heitink se matriks moet aanvoor. Dít is egter ' $n$ langsame proses, en die kerk kan geen kosbare tyd meer deur haar vingers laat glip nie. Om werklik mense op die markplein, in die openbare domein, te bereik, is sowel Heitink as Dingemans se ekklesiologiese model nog te veel vanuit die hoek van die kerk as instelling bedink.

Naas die versorging en begeleiding van gelowiges in gemeentes om via ' $n$ proses van radikale transformasie ' $n$ kerk met karakter te word, sal daar na my mening ' $\mathrm{n}$ tweestroombediening moet wees. Buite die strukture van die kerk as instelling sal gelowiges onbevange moet immigreer om mense op die markplein te gaan ontmoet. Die doel moenie in die eerste plek wees om mense na die kerk te bring nie, maar om die geloof in Jesus Christus diakonaal onder mense sigbaar en voelbaar te maak. Dáár moet ons gaan soek na 'dun' plekke in mense se lewens, waar die skeiding tussen die sigbare werklikheid en die heilige teenwoordigheid van God deur sy Gees vervaag, en mense God se teenwoordigheid ervaar. Juis dáár moet ons leer om afstand te doen van ons meesternarratiewe, en onbevange luister na die klein verhale van mense. Saam met hulle moet ons weer begin luister na die verhale oor God, en probeer ontdek hoe die groot Godsverhaal ons klein verhale omvorm en nuwe sin aan ons lewe gee.

Dit kán wees dat die lyne van hierdie tweestroombediening in die toekoms saamkom. Dít kan egter slegs gebeur indien die NHKA deur die proses van radikale transformasie weer vir mense buite die kerk 'n plek word waar hulle die teenwoordigheid van God kan beleef. Dan kan Heitink se konsentriese sirkels dalk ' $n$ werklikheid word, en sal die 'Sache Jesu' mense ál nader na die middelste kring intrek. Dít is ' $n$ droom - of dit ' $n$ werklikheid sal word, sal net die tyd leer.

\section{LITERATUURVERWYSINGS}

Armour, M.C. \& Browning, D., 1995, Systems-sensitive leadership. Empowering diversity without polarizing the church, College Press, Missouri.

Barna, G., 2005, The state of the church, Ventura.

Barth, K., 1959, Church Dogmatics iv/i: The Doctrine or reconciliation, (reds.) G.W. Bromley \& T.F. Torrance, vertl A.T. MacKay \& T.H.L. Parker, T \& T Clark, Edinburgh.

Bell, R., 2005, Velvet Elvis. Repainting the Christian faith, Zondervan, Grand Rapids.

Berkhof, H., 1979, Christian faith: An introduction to the study of Christian faith, 4de uitgawe, Eerdmans, Grand Rapids.

Borg, M.J., 2003, The heart of Christianity. Rediscovering a life of faith, Harper, San Francisco.

Buitendag, J., 2006, 'Nuwe wyn in nuwe sakke en die behoud van altwee: 'n Herbedinking van die Hervormde Kerk se identiteit aan die begin van die $21^{\text {ste }}$ eeu in Suid-Afrika', HTS Teologiese Studies/Theological Studies 62(2), 343-362.

Callahan, K.L., 2002, The future that has come. New possibilities for reaching and growing the grassroots, Jossey-Bass, San Francisco.
De Roest, H. \& Stoppels, S., 2007, 'Levend liggaam', in R. Brouwer e.a., Levend lichaam. De Dynamiek van christelijke geloofsgemeenskappen in Nederland, n.p., Kok, Kampen.

Dingemans, G.D.J., 2005, De stem van de roepende. Pneumatologie, Kok, Kampen.

Dreyer, T.F.J., 1998, 'Spiritualiteit, identiteit en die etos van die Nederduitsch Hervormde Kerk', HTS Teologiese Studies/ Theological Studies 54(1\&2), 289-314.

Dreyer, T.F.J., 2003, 'Statistieke vertel 'n storie - 'n Visie vir die Hervormde Kerk op pad na 2010', HTS Teologiese Studies/ Theological Studies 59(4), 1045-1062.

Dreyer, T.F.J., 2005, “'Kenotiese" prediking - die katalisator vir liturgiese verdieping in die huidige konteks', HTS Teologiese Studies/Theological Studies 61(93), 93-108.

Dreyer, T.F.J., 2006, 'Die akkommodering en bestuur van diversiteit in gemeenteverband', HTS Teologiese Studies/ Theological Studies 62(4), 1291-1309.

Dreyer, W.A., 2006, 'Die Nederduitsch Hervormde Kerk van Afrika as volkskerk - oorsig en herbesinning', HTS Teologiese Studies/Theological Studies 62(4), 1337-1368.

Dreyer, Y., 2004, 'A public practical theological theory for religious education of secularised youth', HTS Teologiese Studies/Theological Studies 60(3), 919-945.

Firet, J., 1986, 'Kroniek van de praktische theologie', Praktische Theologie 13(5), 589-632.

Hall, D.J., 1995, The end of Christendom and the future of Christianity, Trinity Press, Harrisburg.

Heitink, G., 2007, Een kerk met karakter. Tijd voor heroriëntatie, Kok, Kampen.

Hirsch A., 2006, The forgotten ways: Reactivating the Missional Church, Brazos, Grand Rapids.

Hoekendijk, J.C., 1964, De Kerk binneste buiten, W. Ten Have N.V., Amsterdam.

Knippenberg, H., 2005, The changing religious landscape of Europe, Het Spinhuis, Amsterdam.

Lose, D.J., 2003, Confessing Jesus Christ. Preaching in a Postmodern World, Eerdmans, Grand Rapids.

NHKA, 2009, 'Agenda van die Kommissie van die Algemene Kerkvergadering', Kerkargief, Pretoria, 5 Junie 2009.

Niemandt, N., 2007, Nuwe drome in nuwe werklikhede. Geloofsgemeenskappe in pas met 'n postmoderne wêreld, Lux Verbi BM, Wellington.

Sweet, L., 1999, SoulTsunami, sink or swim in new millenium culture, Zondervan, Grand Rapids.

Sweet, L., 2001, Carpe Manana. Is your church ready to seize tomorrow?, Zondervan, Grand Rapids.

Van Aarde, A., 2008, 'What is "theology" in "public theology" and what is "public" about "public theology"?', HTS Theologiese Studies/Theological Studies 64(3), 1213-1234.

Venter, M., 2008, "n Kritiese vergelyking tussen die ekklesiologieë van G. Heitink en G.D.J. Dingemans toegepas op die NHKA van die een-en-twintigste eeu', MDiv-skripsie, Universiteit van Pretoria.

Ward, P., 2002, Liquid Church, Paternoster Press, Carlisle.

Young, W.P., 2007, The shack. Where tragedy confronts eternity, Windblown Media, Los Angeles. 